\title{
Affirmation of School Management and Success of Islamic Religious Education Learning
}

\author{
Kristo Paulus, Nur Irsyadiah, Ahmad Rifa'i \\ Public Elementary School Utan Kayu Selatan 03 Pagi Jakarta, Indonesia \\ Islamic Religious education at the Islamic University of Jakarta, Indonesia \\ SMA Muhammadiyah 16 Jakarta, Indonesia \\ Email:kristopaulus@gmail.com, nurirsyidiah@gmail.com,dan azka2thn@gmail.com
}

\section{ARTICLE INFO \\ Date received : 01 January 2021 \\ Revision date : 05 February 2021 \\ Date received :06 March 2021}

\section{Keywords:}

Affirmation

Management

Islamic Religious Education

\begin{abstract}
School management is an activity that is carried out effectively and efficiently to improve school performance, including learning Islamic religious education. Therefore it is necessary to affirm that school management will be more organized and focused on goals. Schools that run a good managerial system will certainly pay attention to the quality of education in them so that learning in these schools will run optimally. The object of this research is Islamic education learning in schools with good school management. The research methodology used is qualitative research methods with descriptive methods. The findings in this study show that schools that carry out affirmation of school management will be able to encourage the success of Islamic Education learning in these schools.
\end{abstract}

Coresponden Author:

Email: kristopaulus@gmail.com Article with open access under license

\section{INTRODUCTION}

Islamic Religious Education is given by following the guidance that religion is taught to humans with a vision to realize people who are devout to Allah and have noble morals, and aim to produce human beings who are honest, just, ethical, ethical, respectful, disciplined, harmonious and productive. both personal and social.

Islamic religious education has a role in creating an intelligent, peaceful, open, democratic and moral society.If the results of Islamic Religious Education are to be improved, then changes and improvements must be made, including the refinement of the curriculum.The Ministry of Education and Culture (Depdikbud) plans to change the curriculum starting in the 2013/2014 academic year, as has been done by the Ministry of Education and Culture by changing the education unit level curriculum (KTSP) to the 2013 curriculum. The implementation of the 2013 curriculum will prioritize moral and moral lessons.

The government considers this curriculum to be better than previous curricula, teachers have a very important role in the implementation of the 2013 Curriculum. (Nomor, 81AD) In the 2013 Curriculum students are required to be able to develop attitudes and character, as emphasized in the 2013 curriculum.(A. Ferry T. Indratno, 2013).The implementation of the 2013 curriculum will promote moral and moral lessons.Religion course, which was originally only two hours per week, will be increased to 4 hours per week.

The various components contained in this education often run as they are, naturally and traditionally, because they are carried out without careful concept planning, as a result of this situation, the quality of Islamic education often shows an unsatisfactory condition. (Sulistyorini, 2009: 4) Therefore, to realize these problems, good management is needed, especially after the merger 
of Islamic Religious Education and Character Education in the 2013 Curriculum.

In order for the 2013 Curriculum to be implemented well, management is needed to develop it, management or management is an integral component and cannot be separated from the overall educational process

The reason is that without management, it is impossible for educational goals to be realized optimally, effectively and efficiently. (Mulyasa, 2003)

However, the reality faced now is at odds with the vision, mission and goals of Islamic Religious Education.In several surveys regarding the process of implementing Islamic Religious Education in schools, there are still many obstacles faced.And coupled with the existence of the 2013 Curriculum which combines the subjects of Islamic Religious Education students and Character, so that teachers also still feel confused about the curriculum.

Education is often highlighted in efforts to develop and improve the quality of human resources, however constraints and obstacles result in the low quality of education.Meanwhile in the world of education there are still many worrying examples that are presented, such as laziness, indiscipline, dishonesty, disrespect for parents or teachers and a series of other disgraceful behavior and low achievement. This fact refers to the problem of low morality.Many have the view that low morality is related to the failure of the existing education system, especially Islamic Religious Education.

\section{A. Affirmation of School Management}

1. Definition of School Management Affirmation

Big Indonesian Dictionary, the word "affirmation" has a quite special meaning.The definition of affirmation is a positive determination such as affirmation or affirmation related to something positive.Affirmations are positive, specific self-addressed statements.To achieve success and realize the goals you have, you must have the courage to move forward, no matter what obstacles you must face.Therefore, affirmations are needed in order to achieve success from day to day.Affirmation has 5 meanings.Affirmation is a homonym because the meanings have the same spelling and pronunciation but different meanings.Affirmations have meanings in the class of nouns or nouns so that they can state the name of a person, place, or all objects and everything that is objectified.

Management is generally defined as the process of planning, organizing, directing and monitoring (JejenMusfah, 2015: 2). The efforts of the members of the organization and the use of other organizational resources in order to achieve the stated organizational goals. Management is the use and empowerment of all human resources in order to achieve goals efficiently and effectively. In management, this process is linked to and involves the organization, direction, coordination and evaluation of people in order to achieve these goals. The process includes: planning, organizing, implementing and monitoring (HeriGunawan, 2012: 239). Management is a person's activity in managing human and non-human organizations, institutions or schools, so that the goals of the organization, institution or school can be achieved effectively and efficiently (Sulistyorini, 2009). Sergiovanni said management as a process of working with and through others to accomplish organizational goals efficiently (management as a work process through other people to achieve organizational goals efficiently, in (Bafadal, Nurabadi, Sobri, \& Gunawan, 2019). Thus, management is a management process that starts from planning, organizing, implementing and controlling into a series of real activities by utilizing all related resources to achieve the organization's predetermined goals effectively and efficiently.

Experts define management according to their respective views and approaches as follows:

Made Pidarta management is the center of administration, administration begins and ends in management.Management is the core of administration, because management is the main part of administration, with tasks that most determine administration. This is the essence of management, an activity that is the administrative center, center or core of cooperation between members of the organization to achieve predetermined goals.(Made Pidarta, 1988: 17)According to IwaSukiwa, management is a social process that is planned to ensure effective cooperation, participation, intervention and 
involvement of others in achieving certain or predetermined goals. (Sukiwa, n.d.)

According to Harold Koontz and Cygil O 'Donnel in their book "Principles of Management an analysis of Management Functions" provides the following limitations "management is an attempt to achieve a certain goal through the activities of other people.Thus managers coordinate a number of other people's activities which include planning, organizing, placing, mobilizing and controlling ".(Hasibun, 1993: 3)

Arthur Sharplin defines management as: "management is the conducting or supervising of something (as a business);esp: the executive function of planning, organizing, directing, controlling and supervising "."Management is the implementation or supervision of something (as a business); such as: executive function planning, organizing, directing, controlling and supervising ". (Sharplin \& Seeger, 2007) (Arthur Sharplin, 1985: 6)

James Stoner provides a definition, management is the process of planning, organizing, directing, and monitoring the efforts of members of the organization and the use of other resources within the organization to achieve predetermined goals. (Yani, Susilo, \& Ruhana, 2016) (Susilo, 2008: 71)

Based on some of the definitions of management above, it can be understood that management is a series of activities to plan, organize, mobilize, control and develop all efforts to regulate and utilize human resources, facilities and infrastructure efficiently and effectively to achieve predetermined goals.Management is the process of organizing various activities to achieve goals effectively and efficiently.

School management is an activity that is carried out effectively and efficiently to improve school performance in achieving educational goals, both national goals and institutional goals, the results of which can be seen from several factors as performance indicators achieved by schools. The principal is required to be able to carry out his duties and functions in managing various components of the school to achieve the school goals formulated.The principal shows his function as two major roles, namely the role of manager and the role of leader. (Dall et al., 2008)

School management is an act of managing and administering the school.School management means empowering human resources and other resources to achieve school goals.School management has two aspects, namely external management and internal management.Internal school management includes libraries, laboratories, buildings and other physical advice, sources of funds, implementation of educational evaluations, and relationships between teachers and students.while external management includes relationships with parties outside the school such as the community, the education council, the education office and other parties related to school functions. (Dall et al., 2008)

Affirmation of School Management is the determination or affirmation of an act of school management and administration by empowering human resources and other resources to achieve school goals.

2. Functions and Objectives of School Management

Management function is a series of activities carried out within management based on their respective functions and follows a certain stage in their implementation.From this emerges what is known as the management function. The division of management functions has the following objectives, namely that the order of discussion is systematic, in-depth analysis of the discussion and becomes a guideline for implementing the management process for a manager. (Sofyan Safri Harahap, 2001: 1)

Curriculum management itself has five functions, namely; planning (planning), organizing (organizing), actuating (moving / implementing), controlling (supervision), and evaluating (assessment). Each of these functions has a role and benefits. These activities are management functions which include:

1. Planning

Planning can be defined as the entire process of thinking and determining all activities that will be carried out in the future in order to achieve goals (M. Manullang, 1983: 21). 
Planning is also defined as a process of thinking, predicting, and prioritizing activities that must be carried out rationally before carrying out actual actions in order to achieve goals.(Taslimah Yusuf, 1996: 33)

The functions in planning are as follows:

a. Planning serves as a management guide or tool, which contains instructions on the types and sources of learning, media, teaching materials, education levels, costs and facilities required, as well as a control and evaluation system to achieve pre-designed management goals.

b. Planning functions as a tool or activator of the organization and management to create change in society in accordance with organizational goals.

c. Planning serves as motivation to implement the education system so as to achieve optimal results.

Management in school planning can be defined as the expertise or ability to plan and organize schools. Who is responsible and how the school planning is carried out in a professional manner are two things that need to be expressed in the planning

2. Organizing

Organizing can be seen from two approaches, namely in the management context and in the academic context.

3. Actuating

The implementation of school management is illustrated by the methods taken in school management, including in the management of human resources and school infrastructure.

4. Controlling

Chuck Williams in the book Management, Controlling is monitoring progress toward goal achievement and taking corrective action when progress isn't 56 being made. (Williams \& McWilliams, 2010) "Supervision is the review of progress towards the achievement of the final result and taking corrective action when the progress does not materialize".

Supervision in school management functions to monitor the extent to which implementation is carried out by referring to the previous planning so that in the implementation of the objectives of the school management itself is achieved with the expected goals, because the function of supervision is to oversee the implementation process.

5. Evaluating

Assessment or evaluation is a systematic and planned activity to measure, assess and classify program implementation and success.Assessment should be developed in conjunction with planning a program. Evaluation on evaluation activities is carried out on the input, process, and output components. The results of the evaluation are used for consideration in improving, adding, or developing to a more effective and efficient direction.

Suprihanto, said that the objectives of the evaluation, among others

a. As a tool for improving and planning future programs

b. To improve the allocation of current and future resources, resources and management

c. Improve the implementation and and the factors that influence the implementation of a program planning re-planning of a program by checking the relevance of the program in terms of small continuous changes and measuring the progress of the planned targets.(Suprihanto, 1988: 42).

\section{B. Islamic Religious Education Learning}

1. Definition of Islamic Religious Education Islamic religious education as stated in GBPP PAI in public schools, explains that Islamic religious education is a conscious and planned effort in preparing students to know, understand, live, and teach Islam, coupled with demands to respect adherents of other religions in relation toharmony between religious communities to create national unity and unity. (Muhaimin, 2005)

Islamic religious education subjects are part of national education, in the National Education System Law 
(Sisdiknas) No.20 of 2003 article 11 paragraph (6) explains that religious education is education that prepares students to be able to carry out roles that require mastery of special knowledge about the teachings of the religion concerned. The whole subject of Islamic religious education is within the scope of the Qur'an and Al-Hadith, faith, morality, fiqh, and history, as well as illustrating that the scope of Islamic religious education includes the realization of harmony, harmony and balance in human relations with Allah SWT.oneself, fellow humans, other creatures and their environment (Hablumminallahwahablumminannas).

Religious education is one of the three subject matters that must be included in the curriculum of every formal education institution in Indonesia.This is because religious life is one of the dimensions of life that is expected to be integrated.(ChabibThoha, 1999: 1)

Islamic Religious Education is an effort to nurture and nurture students so that they can always understand Islam completely.Then live the goal, which in the end can practice and make Islam a way of life. (Andayani \& Majid, 2004). Terminologically, Islamic religious education is oriented not only to providing religious knowledge which is Islamological in nature, but rather emphasizes the educational aspects in the direction of forming a Muslim person who is obedient, knowledgeable and does good deeds.

Experts have their own interpretation of the meaning of Islamic religious education, here are some opinions from experts regarding Islamic religious education :

1. According to M. Yusuf al-Qardhawi, Islamic religious education is the education of the whole human being, his mind and heart, spiritual and physical, morals and skills.Therefore, Islamic religious education prepares humans to live in a state of peace and war, and prepares them to face society with all its good and evil, sweet and bitter. (Al-Qaradawi, 2004)
2. Islamic religious education is a personal and societal arrangement that is why it is possible to embrace Islam logically and accordingly as a whole both in individual and collective life.(Ali Zainuddin, 2007: 43)

3. Islamic religious education is an effort made by educators to students for recognition and recognition of the correct places of everything in the order of creation so as to lead to recognition and recognition of God's proper place in the order of form and personality. (Hasbullah, 1996)

4. Islamic religious education is education through the teachings of the Islamic religion, namely in the form of guidance and care for students so that later after completing that education they can understand, live and practice the teachings of Islam that they have believed thoroughly and makethe teachings of Islam as a view of life for the safety and welfare of life in the world and in the hereafter.(ZakiahDaradjat, 2006: 97)

5. Islamic religious education is a transisternalization process or transaction of Islamic knowledge and values to students through teaching, habituation, guidance, nurturing, supervision, and potential development, in order to achieve harmony and perfection in life in the world and the hereafter.(Ramayulis, 2002: 38)

6. H. Haidar Putra Daulay, argued that Islamic religious education is basically education that aims to form a complete Muslim personality, develop all human potential both in physical and spiritual form. (Daulay \& Pasa, 2016)

2. Purpose and Function of Islamic Religious Education

Purpose and Function of Islamic Religious Education Purpose means something that is aimed at, which is to be achieved by a business or activity. In Arabic it is stated as ghayat or maqasid. While in English, the term goal is 
expressed as "goal or purpose or objective". (M. Arifin, 1991: 222). Islamic religious education aims to foster religious people, meaning humans who are able to carry out the teachings of Islam properly and perfectly, so that it is reflected in attitudes and actions throughout their life, in order to achieve happiness and glory in the world and the hereafter. Which can be cultivated through intensive and effective religious teaching. (ZakiahDaradjat, 2006: 172) The purpose of Islamic religious education is identical to the goal of Islam, because the goal of religion is that humans have strong beliefs and can be used as a guide for their lives, namely to develop a round personality pattern and through various business processes that are carried out. Thus the goal of Islamic Religious Education is an expectation desired by Islamic educators themselves.

Islamic religious education in schools is intended to shape students into mausia who believe and fear their god, have a noble character and develop spiritual potential in students. Noble morals include ethics, manners, and morals as a manifestation of religious education.Spiritual potential includes the recognition, understanding and cultivation of religious values as well as the practice of these values in everyday life.Therefore, Islamic Religious Education is indispensable in fortifying students in fortifying themselves from the influence of the times and the culture of globalization.

Ahmad Sabri (2005: 34) says: "These changes are :

1. Intensional, namely changes that occur due to experience or practice, the learning process deliberately and consciously, not by chance,

2. Positive-active, change that is positive-active.Change is positive, namely changes that are useful in accordance with student expectations, in addition to producing something new and better than before, while changes that are active are changes that occur because of the efforts made by students, not happen by themselves,

3. Effective functional, changes that are effective, namely where there are changes that provide influence and benefits for students.As for those that are functional, namely changes that are relatively fixed and can be produced or utilized whenever needed ".

The success in shaping students into human beings who have intellectual, emotional and spiritual intelligence depends on the quality of learning. HusnulAtiyah (in A. Rifqi Amin, 2012: 7) said: "The teaching and learning process can run well if an educator is able to manage the available time as best as possible.

3. Characteristics of Islamic Religious Education

Each subject has certain characteristics or characteristics that can distinguish it from other subjects, including the subject of Islamic Religious Education (PAI).The characteristics of Islamic Religious Education referred to are :

a) Islamic Religious Education (PAI) is a family of subjects developed from the main (basic) teachings contained in Islam. That is why Islamic Religious Education (PAI) is an inseparable part of Islamic teachings.In terms of its content, Islamic Religious Education (PAI) is the main teaching that is one of the components, and cannot be separated from the family of subjects that aim to develop the morals and personalities of students.

b) The purpose of Islamic Religious Education (PAI) is to form educators who believe and fear Allah SWT, have noble character (have noble character), have knowledge of the main teachings of Islam and practice them in everyday life, and have extensive knowledge.and profound about Islam so that it is adequate both for social life and for continuing to study at a higher level. 
c) Islamic Religious Education (PAI), as a learning program, is directed at

1) maintaining the aqidah and devotion of students,

2) becoming a foundation to be more diligent in studying other sciences taught in schools / madrasas,

3) encouraging students to be critical, creative and innovative and

4) make the foundation in everyday life in society.Islamic Religious Education (PAI) not only teaches knowledge about Islam, but also to be practiced in everyday life (building social ethics).

d) Learning Islamic Religious Education (PAI) not only emphasizes cognitive mastery, but also affective and psychomotor.

e) The content of the Islamic Religious Education (PAI) subject is based on and developed from the provisions contained in the two main sources of Islamic teachings, namely the AlQur'an and the Sunnah of the Prophet Muhammad SAW (dalilnaqli). In addition, the material of Islamic Religious Education (PAI) is also enriched with the results of istinbath or ijtihad (dalilaqli) of the scholars so that the main general teachings are more detailed and detailed.

f) Islamic Religious Education (PAI) materials are developed from three basic frameworks of Islamic teachings, namely aqidah, syari'ah and morals.Aqidah is a translation of the concept of faith.Syari'ah is a translation of the Islamic concept and morals is a description of the concept of ihsan.From these three basic concepts, various Islamic studies have developed, including studies related to science, technology, arts and culture.

g) Out Put Islamic Religious Education (PAI) learning program in schools / madrasas is the formation of students who have noble morals (noble character) which is the main mission of the sending of the Prophet Muhammad SAW, in this world. Moral education (character) is the soul of education in Islam, so that the attainment of noble morals (karimah) is the real goal of education. In this connection, it needs to be emphasized that Islamic Religious Education (PAI) learning is also a need of students that cannot be ignored. However, the attainment of noble morals has difficulties if it is only considered to be the responsibility of the Islamic Religious Education (PAI) subject. Thus, the achievement of noble morals must be the responsibility of all parties including non-Islamic religious education (PAI) subjects and teachers who teach them. This means that even though morals seem to be only the subject of Islamic Religious Education (PAI), other subjects also need to contain moral content. More than that, all teachers must pay attention to the morals of students and try to instill them in every learning process. So, achieving noble morals is not enough only through the subject of Islamic Religious Education. (HMgs. Nazarudin, 2007: 16).

\section{METODE}

The design of this research is Literature Review which is to collect data or sources related to a particular topic obtained from various sources such as books, journals, encyclopedias, newspapers, magazines and other libraries. Literature review is or critically review the knowledge, ideas or findings in a library and formulates theoretical and methodological contributions to a particular topic. The nature of this research is descriptive analysis that is the regular decomposition of data that has been obtained and then given understanding and explanation in order to be well understood by the reader.

\section{RESULTS AND DISCUSSION \\ A. Role and Function of Principal in School Management Affirmation}

Principal comes from two words namely "Principal" and "School". The word head can be defined as the chairman or leader in an organization or institution. Meanwhile, the word 
school is defined as an institution where it is a place to receive and give lessons.In short, the principal can be defined as the leader of a school or an institution where a place to receive and give lessons. Wahjosumidjo (2005: 83) defines the principal as a functional teacher who is given the task of leading a school where teaching and learning processes are held, or a place where there is interaction between the teacher who gives lessons and students as recipients of lessons.

From the above definition, simply the notion of the principal is a functional teacher who is assigned the task of leading a school where a teaching and learning process is held or a place where there is interaction between the teacher who gives lessons and students who receive lessons. With this the principal can be called a leader in the education unit whose job is to carry out the management of the education unit he leads.

At the operational level, the principal is a person who is positioned at the forefront of coordinating efforts to improve quality learning.The principal is appointed to occupy a position responsible for coordinating joint efforts to achieve educational goals at the level of the school being led.Of course the Principal is not the only one who is fully responsible for a school, because there are many other factors that need to be taken into account.Apart from school principals, there are teachers who are seen as a key factor dealing directly with students and other factors such as the environment that affect the learning process. However, the principal has a role that influences the running of the existing system in schools.

In order for schools to achieve their goals effectively and efficiently, the principal must carry out managerial functions such as planning, organizing, directing, providing motivation, implementing, organizing control, evaluation and innovation.A good principal is expected to form a good learning implementation as well.If learning in school is good, of course it will result in good achievement both for students and teachers.

The duties of the principal as written in Permendiknas no.13 of 2007 concerning Principal Standards are described as follows:

a. Prepare school / madrasah plans for various planning levels.

b. Developing school / madrasah organizations in accordance with the needs in order to make efficient use of school / madrasah resources.

c. Managing change and development of schools / madrasahs towards effective learning organizations.

d. Manage school facilities and infrastructure in order to optimize utilization.

e. Manage school relationships with the community in order to seek support for ideas, learning resources, and school funding.

f. Managing students, especially in the context of new student admissions, student placement, and student capacity building.

g. Manage curriculum development and teaching and learning activities in accordance with the direction and goals of national education.

h. Managing school administration in supporting school activities.

i. Managing school special service units in supporting learning activities and student activities in schools (Ladjid, 2005).

j. Applying entrepreneurial principles in creating innovations that are useful for school development.

k. Creating a culture and work climate that is conducive to student learning.

I. Manage school information systems in support of programming and decision making.

m. Take advantage of advances in information technology for improving learning and school management.

n. Manage production / service activities in support of school funding sources and as a source of student learning.

o. Supervise the implementation of school activities according to applicable supervisory standards.

From the above explanation, it can be concluded that the principal's duties as managerial consist of organizing, assigning personnel according to their fields, giving responsibility to their subordinates, the ability to motivate their subordinates, and supervision through supervision or control.

In managing educational personnel, one of the duties the principal must do is to carry out maintenance and professional development activities for teachers.Teaching and learning activities are at the core of the education process and teachers are the main 
implementers and developers of the curriculum in schools.Principals who show high commitment and focus on curriculum development and teaching and learning activities in their schools will of course really pay attention to the level of competence of their teachers, as well as will always try to facilitate and encourage teachers to continuously improve their competence, so that teaching and learning activitiescan run effectively and efficiently.

This is where affirmation needs to be done by the principal in school management in order to improve learning Islamic Religious Education.By encouraging religious teachers to carry out their duties through a system of control and provision of facilities that support the success of learning Islamic Religious Education in schools. The principal as the creator of a work climate creates a culture and a conducive work climate that will allow each teacher to be more motivated to show superior performance, accompanied by efforts to improve their competence (Tuma, J. M., \& Pratt, J. M. (1982). Clinical child psychology practice and training: A survey. Vlots of Clinical Child \& Adolescent Psychology, 137(August 2012) et al., 2002).

\section{B. School Management Affirmation Model}

Some things that need to be considered in learning Islamic Religious Education (PAI) are as follows:

1) Islamic Religious Education (PAI) as a conscious effort, which is an activity of guidance, teaching and / or training carried out in a planned manner and aware of the goals to be achieved.

2) Students who want to be prepared to achieve goals; in the sense that someone is guided, taught and / or trained in increasing belief, understanding, appreciation and experience of the teachings of Islam.

3) Educators or Teachers of Islamic Religious Education (GPAI) who carry out guidance, teaching and / or training activities consciously for their students to achieve the goals of Islamic religious education (PAI).

4) Activities (learning) Islamic religious education (PAI); learning activities are directed at increasing students' belief, understanding, appreciation and practice of Islamic religious teachings; in addition to forming keshalehan (personal qualities) as well as to form social keshalehan. In a sense, the quality or personal devotion is expected to be able to radiate out in daily relationships with other humans (in the community), both of the same religion (fellow Muslims) and those who are not of the same religion (relations with nonMuslims) and in the nation and state so that unity and unity can be realized. national (ukhuwahwathaniyah) and even ukhuwahinsaniyah (Zaenal Arifin, 2009: 12)

By paying attention to the learning of Islamic Religious Education, the principal needs to implement school management that supports the success of this learning.Schoolbased management is a management model that provides greater autonomy to school principals, provides flexibility to schools, encourages direct participation from school members.(Rohiat, Saridewi, 2008)

School-based management is a school management model by giving greater authority at the school level to directly manage its own schools so that schools have the responsibility in determining school programs.SBM is a form of decentralization reform that encourages democratic participation.(Nurkolis, 2003).School Based Management is to improve the efficiency, quality and equity of education.Increased efficiency is achieved through the flexibility to manage existing resources, community participation, and simplification of the bureaucracy. The implementation of School Based Management requires the support of a skilled and qualified workforce in order to generate more productive work motivation and empower local authorities, as well as streamline the system and eliminate overlapping bureaucracy (Suryosubroto, 2004).

School-Based Management provides opportunities for principals and teachers as well as students to innovate and improvise in schools, related to curriculum, learning, managerial, and so on, that grow from their activities, creativity and professionalism.The authority that rests on the school is at the core of the School Management Affirmation which is considered to have a high level of effectiveness and provides the following benefits:

1) school policies and authorities have a direct influence on students, parents and teachers

2) aims at how to utilize local resources.

3) effective in coaching students such as attendance, learning outcomes, 
repetition rates, dropout rates, teacher morale, and school climate

The effectiveness of the application of School Based Management is based on the following 6 points:

1) Autonomy, flexibility and responsiviats

2) Planned by the principal and the school community.

3) Implementation or adaptation of new rules by the principal.

4) Participation from the school environment.

5) Collaboration between staff

6) Good relations between the principal and the teacher

Characteristics of School Based Management

1) The school has the expected output

2) The management process has the following characteristics:

a) Has a high effectiveness of teaching and learning activities.

b) Strong school leadership.

c) A safe and orderly school environment.

d) Effective management of education personnel.

e) The school has a quality culture.

f) The school has a teamwork that is compact, intelligent and dynamic.

g) The school has the authority (independence).

h) High participation from school members and the community.

i) The school has openness (management transparency).

j) School has a will to change (psychological and physical).

k) The school conducts evaluation and improvement on an ongoing basis.

I) The school is responsive and anticipatory to needs

m) The school has good accountability and communication.

n) The school has good environmental management.

o) Schools have the ability to maintain sustainability

3) Educational input:

a) Have a clear quality policy, goals and objectives.

b) Resources are available and ready

c) Competent and dedicated staff.

d) Have high performance expectations.

e) focus on management and customers (especially students)

With the established school-based management, the principal can make school management affirmations that support the school culture.School culture is a set of values that underlie behavior, traditions, daily habits, and symbols practiced by school principals, educators / teachers, educational / administrative personnel, students, and the community around the school.School culture is a characteristic, character or character, and image of the school in the wider community.

A school must have a mission to create a school culture that is challenging and fun, fair, creative, innovative, integrated, and dedicative to the achievement of the vision, producing graduates who are of high quality in their intellectual development and have a piety, honest, creative character, able to be role models, work hard, tolerant and competent in leading, as well as responding to challenges of human resource development needs that can play a role in science and technology development and based on faith. The demands of a professional school require proper management through the implementation of School Based Management.Thus, the institution can make an inventory of its strengths and needs, weaknesses, opportunities, obstacles, and challenges that may exist.

In the context of implementing School Based Management, Sergiovanni (2005) suggests that policy makers, supervisors and principals use the school culture approach. With the following considerations:

1) The cultural approach emphasizes the human factor more than other factors. The role of humans is very central in a process of planning change. According to the adage man behind the gun, humans are the determining factor for successful change, not legal structures or regulations.

2) The cultural approach emphasizes the importance of the role of values and beliefs in humans. This aspect is an element that is very influential in shaping attitudes and behavior. Therefore, the cultural approach prioritizes the transformation of values and beliefs before legal-formal changes (Arief, 2002).

3) The cultural approach provides respect and acceptance of existing differences. An attitude of acceptance and mutual respect will create mutual trust and togetherness among members of the organization. A sense of togetherness 
will lead to cooperation, and cooperation will create professionalism that brings change so as to change old values that are hindering with new values that support School Based Management.

Schools are given the freedom to make work programs by the government through Graduate Competency Standards (SKL) which is one of the eight national education standards as stipulated in the Minister of National Education Regulation (Permen) No.23 of 2006. School managers must build a system in whichprioritizing cooperation or team work.Success is built on the basis of togetherness and not the work of one principal or one man show. The principal of each period will change, but the system will continue to run alongside whoever the leader is.

\section{Steps for School Management Affirmation and the Success of Islamic Religious Education}

To carry out the affirmation of school management that has been determined, the principal of the concept of management information systems actually existed before computers appeared, namely where all kinds of information within the organization were processed quickly, thoroughly and reliably.However, without a computer the concept is only a theory.Now, with computers, this conception has become a reality. The composition of a system basically consists of an input unit, a processing unit and an output unit.Input or input enters the system through the input unit.Furthermore, the input is processed by the processing unit and the results are displayed or printed out through the output unit which is plugged in, turned on and continues to generate heat until the tool is turned off.There is no way to control the output here.

Information system is a conceptual system that uses conceptual resources, data and information, to represent a physical system, in this case a company or organization.Information systems help managers and leaders of companies or certain organizations to get a picture of the company. The information obtained is an important input for managers in making decisions.(Eko Nugroho, 2008: 16-18)

The basic concept of the information system itself has more clearly things that must be considered, namely:
1. Components and types of information systems, components consisting of blocks that interact with each other to achieve goals, among these blocks are as follows.

a. Block input (input block), which is meant by input here includes methods and media to capture data to be entered in the form of basic documents.

b. Block model (block model), consists of a combination of procedures, logic and mathematical models that will manipulate input data and data stored in the database.

c. Output block (output block), the output which is quality information and documentation that is useful for all levels of management.

d. Technology block (technology block), is a tool box in information systems. Namely as a means of receiving input, running models, storing and accessing data, generating and sending output and helping control of the system as a whole.

e. Database block (database block), a collection of data that are interrelated with one another.

f. Control block (control block), controls designed and implemented to ensure that things that damage the system can be prevented and the errors that occur can be resolved as soon as possible.

2. Planning information systems.Information system planning materials to be discussed revolve around four levels, namely idea, design, implementation and evaluation.

a. Ideas, namely the idea of knowing the need for change.

b. Design, which is designing a solution.

c. Implementation, namely applying the design to the system.

d. Control, namely checking whether the level of implementation is in accordance with the design.

e. Evaluation, which is checking whether the changes that occur are in accordance with the original purpose.

f. Follow-up, namely implementing changes in accordance with existing evaluation results.

3. Management of information systems

An effective leader is in charge of and responsible for managing the information system within the framework of the 
management process and the implementation of management functions. The management duties include information planning, information transformation, information communication, implementing organization, monitoring and control.

4. Control of information systems

Control aims to ensure management and information products in terms of quality, quantity and timeliness.Controlling information is carried out through supervision and guidance.

5. Information system assessment

The function of information appraisal is to provide information for consideration in making decisions.Assessment is applied in three important components of information systems, namely information system management consisting of input (the initial step of compiling information), processes (information transformation) and products (results and impacts of information systems).(Tata Sutabri, 2004: 35-45)

To develop a School Management Information System, there are several ways that can be done, including:

1. Systems development life cycle method According to Raymond Mc Leod (1995) quoted from Eko Nugroho (2008) formulating that the SHPS system consists of five phases, with the first four phases provided for development and the fifth phase for use.Each phase requires the participation and cooperation of information users and technicians. The phases are:
a) The planning phase
b) Analysis phase
c) The design or design phase
d) The implementation phase
e) The evaluation phase

2. Prototyping method

The development steps used the prototype method, namely:

a) Identification of organizational needs. This stage is similar to the planning and analysis stages of the SHPS method, but with compacted time and activities.

b) Development of prototypes, development tools can use software suitable for rapid development. c) Prototype test and evaluation, this step aims to determine whether the prototype is acceptable or not.

d) Using a prototype, in this phase the prototype is used so that the status is no longer a prototype, but an operational system.

3. Rapid process development method

The development of a fast development method usually uses a software called CASE, which is a type of software that can be used to develop a SIM quickly. This software has three sub-modules, namely a submodule for compiling a model concept, a submodule for compiling a data and information design dictionary and a submodule for system development (Azizy, 2003).

\section{CONCLUSION}

In managing educational personnel, one of the duties the principal must do is to carry out maintenance and professional development activities for teachers. Teaching and learning activities are at the core of the education process and teachers are the main implementers and developers of the curriculum in schools. Principals who show high commitment and focus on curriculum development and teaching and learning activities in their schools will of course really pay attention to the level of competence of their teachers, as well as will always try to facilitate and encourage teachers to continuously improve their competence, so that teaching and learning activities can run effectively and efficiently. Affirmations need to be made by the principal in school management in order to improve learning Islamic Religious Education. By encouraging religious teachers to carry out their duties through a system of control and provision of facilities that support the success of learning Islamic Religious Education in schools. The principal as the creator of a work climate creates a culture and a conducive work climate that will allow each teacher to be more motivated to show superior performance, accompanied by efforts to improve their competence.

A school must have a mission to create a school culture that is challenging and fun, fair, creative, innovative, integrated, and dedicative to the achievement of the vision, producing graduates who are of high quality in their intellectual development and have a piety, honest, creative character, able to be role models, work hard, 
tolerant and competent in leading, as well as responding to challenges of human resource development needs that can play a role in science and technology development and based on faith. To improve the quality of Islamic Religious Education, School Management Affirmation is needed, which involves:

1. Principal as school manager

2. Teachers as class managers

In affirmation, school management can be carried out by direct methods (the principal carries out supervision of the activities that have been carried out), system methods (making rules made through the School Management Information System).With the system method, the principal of the system will continue to be based on a joint decision with the school education board..

\section{REFERENCES}

A. Ferry T. Indratno. (2013). Menyambut Kurikulum 2013. Jakarta: Kompas Media Nusantara.

Al-Qaradawi. (2004). Pendidikan Islam dan Madrasah Hasan Al-Banna, terj. Bustami A. Gani dan Zainal Abidin Ahmad. Jakarta: Bulan Bintang.

Andayani, Dian, \& Majid, Abdul. (2004). Pendidikan Agama Islam Berbasis Kompetensi. Bandung: Remaja Rosdakarya.

Arief, Armai. (2002). Pengantar IImu dan Metodologi pendidikan islam. Ciputat Pers.

Azizy, A. (2003). Qodri A. Pendidikan [Agama] Untuk Membangun Etika Sosial, Semarang: Aneka IImu.

Bafadal, Ibrahim, Nurabadi, Ahmad, Sobri, Ahmad Yusuf, \& Gunawan, Imam. (2019). The Competence of Beginner Principals as Instructional Leaders in Primary Schools. International Journal of Innovation, Creativity and Change, 5(4), 625-639.

Dall, Keltie L., Scarpini, Cinzia G., Roberts, Ian, Winder, David M., Stanley, Margaret A., Muralidhar, Balaji, Herdman, M. Trent, Pett, Mark R., \& Coleman, Nicholas. (2008). Characterization of naturally occurring HPV16 integration sites isolated from cervical keratinocytes under noncompetitive conditions. Cancer Research, 68(20), 8249-8259.

Daulay, Haidar Putra, \& Pasa, Nurgaya. (2016). Pendidikan Islam dalam Lintasan Sejarah.
Kencana.

Hasbullah, Drs. (1996). Kapita selekta pendidikan Islam. Jakarta: RajaGrafindo Persada.

Ladjid, Hafni. (2005). Pengembangan Kurikulum Menuju Kurikulum Berbasis Kompetensi. Jakarta: Quantum Teaching.

Muhaimin. (2005). Pengembangan kurikulum pendidikan agama Islam: di sekolah, madrasah, dan perguruan tinggi. RajaGrafindo Persada.

Mulyasa, Enco. (2003). Manajemen Berbasis Madrasah. Konsep Strategi Dan Implementasi,(Bandung: Rosdakarya.

Nomor, Permendikbud. (81AD). A Tahun 2013, Implementasi Kurikulum, Lampiran IV. Pedoman Umum Pembelajaran: Jakarta.

Sharplin, Arthur, \& Seeger, John. (2007). A Troubled Time in the Courtyard. The CASE Journal.

Sukiwa, Iwa. (n.d.). Dasar-Dasar Umum Manajemen Pendidikan,. Bandung.

Sulistyorini, Prastuti. (2009). Pemodelan visual dengan menggunakan uml dan rational rose. Dinamik, 14(1).

Suryosubroto, Buwang. (2004). Manajemen pendidikan di sekolah. Rineka Cipta.

Tuma, J. M., \& Pratt, J. M. (1982). Clinical child psychology practice and training: A survey. Vldots of Clinical Child \& Adolescent Psychology, 137(August 2012), 37-41. http://doi.org/10.1037/a0022390, Gobry, F. (1999). $\{$ T $\}$ his is a title. $\{\mathrm{M}\} y$ Journal, $1,120-$ 130., Keshav, S. (2007). How to Read a Paper. Work, 37(3), 83-84. http://doi.org/10.1145/1273445.1273458, et al. (2002). Middlesex University Doctor of Professional Studies. Studies in Higher Education.

Williams, Chuck, \& McWilliams, Alan. (2010). MGMT. South-Western Cengage Learning.

Yani, A., Susilo, H., \& Ruhana, I. (2016). Pengaruh Penempatan Karyawan Terhadap Motivasi Dan Kinerja (Studi pada karyawan PT Perkebunan Nusantara X (PG Watoetoelis) Sidoarjo). Jurnal Administrasi Bisnis S1 Universitas Brawijaya, 30(1), 178-185. 